\title{
Business Model Innovation Furniture and Accessories
}

\author{
M Yasser Iqbal Daulay ${ }^{1}$, Afrima Widanti ${ }^{2}$, Akram Harmoni Wiardi ${ }^{3}$ \\ Department of Management Economy and Business - Universitas Bengkulu 1,2,3 \\ \{iqbaldaulay@unib.ac.id $\left.{ }^{1}\right\}$
}

\begin{abstract}
This research aims to design a business model (Cozzy.com) platform of innovative furniture and accessories with the addition of bundling products based on design, customized and matching space. The design of business models based on nine components of the business model. Collecting data using interviews and a survey of potential customers. The results of the study explain that Cozzy Creative Indonesia needs to target two sides of consumers together. Digital media is the main channel that companies need to do to reach broad customers. Product grouping based on the type of design, and the availability of custom products are the value propositions that will be offered to customers.
\end{abstract}

Keywords: Business Model Canvas (BMC); Multisided Platform; Business Model Innovation

\section{Introduction}

The growth of the furniture industry in Indonesia shows enormous potential. One of the driving factors is the construction of property objects, such as housing, apartments, and rusunami (property rights flats). The growth in the construction of property objects is the impact of the gap between the number of built houses and the required number (backlog) of 13.5 million units [1] DKI Jakarta, Bandung and Yogyakarta are the hree areas with the most active propertydevelopments in Indonesia. DKI Jakarta ranks first in terms of apartment project development, where up to 2019129 apartment projects will be established [2]. Bandung City has 70,616 housing units and 33 apartment projects. Meanwhile, Yogyakarta has 16,992 housing units and 23 housing projects has existed, and will be built. The Indonesian Ministry of Industry explained that the prop erty industry has a chain effect on 175 industrial products, such as furniture [3]. Cosseboom (2015) predicts that the furniture business transactions in Indonesia in 2018 will reach USD 5.5 billion (IDR 77 trillion).

Business potential in the furniture industry, researchers will innovate existing business models. The innovation that Cozzy.com will do is grouping furniture and accessories products based on interior design styles, as well as customization features. Then the response will be with the platform business model canvas of PT Cozzy Creative Indonesia.

Based on the analysis of the observation data on the furniture product platform and accessories. Most companies are online markets for furniture products and accessories. There are two companies, namely IKEA and Fabelio producing its own products under its own company brand. IKEA does cooperation with furniture workshops in Indonesia, where design designed by IKEA company. Meanwhile, Fabelio did his thing which is almost the same as IKEA where the company designs its own products and the work is left to the furniture 
workshop. However, Fabelio too provide space for other companies to offer their products on company website page. Meanwhile, there are three companies that are providing customized facilities such as Fabelio, Qlapa, and Bukalapak.

Fabelio offers consumers customization of orders according to product designs are available, where consumers can only change sizes and the color of the product provided by the company. Another case with Fabelio, Qlapa and Bukalapak are online markets for traders and craftsmen. These two companies, through partner traders and craftsmen, offer products according to the order, on the aspects of color, size, and writing on some accessories.

Lazada, Tokopedia, and Bukalapak are not competitors directly on the furniture industry. The three companies did not provide additional features of product grouping such as, bathroom, bedroom, and room family room. Of the 10 existing companies, only Livaza grouped them products with an interior style like industrial. Meanwhile, nine other companies classify and offer products generally without style differentiator.

Based on several factors that have been presented, such as increase growth of internet users, growth of the consumption class, market opportunities furniture industry, consumer desires for custom made products, and design grouping. Based on observations on 10 provider sites existing furniture and accessories in Indonesia have new business opportunities by innovating on existing business models. As for innovation what the Cozzy.com company will do is product grouping furniture and accessories based on interior design style, and customization features. Then the business model canvas will respond the PT Cozzy Creative platform Indonesia.

Based on the external environmental exposure, Cozzy.com has an opportunity potential to develop in Indonesia. Internet user growth, consumption class growth and backlog housing in Indonesia creates community needs for furniture and accessories products. Other than that, growing trends in interior style encourages consumer desire has occupancy in accordance with the characteristics and style of the middle interior become a trend. The limited dimensions of the room and the limitations of the product are interesting that fits the size of space the consumer has, creates one product opportunities according to the order.

The diversity of consumer desires based on characteristics and styles owned, based on a competitor analysis of the current 10 companies only offers products in general without grouping products according to characteristics and styles of consumers. The characteristics and styles in question refer to design styles, such as industrialist, vintage, retro, pop art, Scandinavian, bohemian, and minimalist modern. These factors are driving forces the development of the company because the products offered are different from those offered by competitors. Based on these conditions, it is necessary to formulate a model design innovative furniture and accessory product platform business with new concepts, namely product services to order and product grouping based on interior style. The design of this business model will serve as a guide in Cozzy.com business development.

The purpose of this research is to design a platform business model innovative furniture and accessories products with additional services attractive consumers. This business model will be described through an approach empathy map and depicted through the business model canvas. 


\section{Literatur Review}

\subsection{Multisided Platform}

Multisided platform (MSP) is part of a business model that develops along with advances in information technology. This business model serves two or more mutually exclusive groups of customers dependence [4]. Company for that matter act as an intermediary or service provider between a group of customers with other customer groups. Alibaba.com is one example of a company that has successfully implemented a business model MSP. Both groups of exporters and importers who come from different Countries are brought together through the company website channel.

According to Hanna (2013) that the pattern created from a multi-faceted platform is creating value through affiliation relationships directly with customer groups. The platform company will be affiliated with its customers in the future accommodate interactions between one group of customers with groups other customers. The company affiliate scheme will form monetization strategy which is the company's strategy in obtaining income. According to Sabourin (2016), there are three monetization models applied by internet companies today, namely free paid, above the line, and monetization asymmetry.

\subsection{Business Model}

According to Osterwalder [5], the concept of a business model can help managers, entrepreneurs and developers capture, understand, communicate, design, design, analyze, and change business in companies. Several researchers have developed various definitions of business models. However, the notion of a business model can be described through fundamentally different theoreticals [6] First, a definition that describes the rationale for porters' value chain, such as the flow or flow in the company that is used to explain the functions or activities of the organization.

Second, describe the company's resources. This definition focuses on the management assets or resources owned by the company. Third, the concept of a business model is described as architecture or design with the idea of value creation at its core [6]. Based on these three definitions, conceptually the business model can be defined as the interpretation of activities, resources, and value creation design in the company.

Chesbourgh [7] describes a business model in two functions, namely capturing and creating value with implications for meeting customer needs. The definition of a business model is seen from its components, as stated by Ostewalder et al. [4] that a business model is a conceptual tool consisting of a collection of elements and their relationships in expressing the company's business logic. Furthermore, the notion of a business model as a business strategy is a business model that is used as a tool to formulate a company's business strategy. In general, a business model can be defined as a description of the relationship between advantages and resources owned by the company.

Business models can provide opportunities for managers to capture the potential and strength of technology, both internally and externally. Furthermore, companies can commercialize through the selection of value propositions, market segments, value chains, cost structures, profit potential, networks, and competitive strategies. In addition, a business model can also serve as a link between technological 
innovation and consumers or between technology and resources in the company.

In general, the purpose of using a business model within a company is as a tool that can be used to analyze the condition of the company's activities. Analysis obtained froma business model can describe activities, processes, flows, and business relationships with company partners. In addition, the business model can also be used as a tool to mediate between technology or ideas and potential customers. Where this goal will have an impact on the company's method of capturing and delivering value to customers.

\subsection{Business Model Canvas}

The business model canvas is a business model that describes the rationale for how an organization or company creates, captures, and delivers value to customers [5]. The business model canvas is a business model ontology, where the characteristics of this business model are trying to explain the overall and concrete business picture. The application and use of the business model canvas in a business context is a tool that describes the business model of a company.

The business model canvas is made up of nine building blocks that show the logic of how companies make money. Coes [8] explains that these building blocks can be structured through four dimensions of the business model, namely the value proposition, the architecture of the relationship between the company and its partners, the architecture in the company's activities, and financial aspects. Meanwhile, Ostewalder and Pigneur [8] explain that these nine canvas blocks cover four main business areas, namely customers, offering, infrastructure, and financial feasibility. The nine canvas blocks consist of customer segments, value proposition, channels, customer relationships, revenue streams, key activities, key resources, core partners, cost structure [8].

\section{Methodology}

The method used in writing PT Cozzy Creative Interior's business model is descriptive qualitative. The advantage of using this method is that the author gets a variety of variables that come from existing business actors or potential customers. Research using a qualitative approach is aimed at obtaining decision areas, namely retail design, new product development, process understanding, and market segmentation.

Qualitative research has a tendency to use a small sample size because the purpose of research is to get an in-depth understanding of something [9]. To get an understanding of the furniture and accessories service business, the units of analysis in this study are electronic trading companies, individual consumers, and furniture and accessories company owners. Qualitative research is depicted from various data sources, namely from individuals, companies and existing business environments [9]. This study uses data sources which are grouped into two, namely primary and secondary data. Primary data obtained through several instruments such as surveys, interviews and observation

The survey in this study aims to obtain information about the needs of individual potential consumers for furniture and accessories products through the empathy 
map technique. The data collection tool used is a questionnaire distributed to individual prospective Cozzy.com consumers domiciled in Jakarta, Bandung and Yogyakarta through Google Forms media. Meanwhile, the sample in this study was 40 respondents. This sample size refers to Roscoe [16] that a sample size of 30 and less than 500 is appropriate for use in research. The consideration for selecting the three cities is based on the Cozzy.com business operating area.

The data analysis method used in this research is descriptive qualitative analysis. This analysis focuses on the interpretation of content from filling out questionnaires by respondents and the results of interviews. The data obtained will then be described using empathy map analysis techniques and followed by the formation of a business model canvas. The analysis technique using this empathy map aims to see the factors of the research subject, both consumers and furniture and accessory product companies. The empathy map analysis refers to the concept of Osterwalder and Pigneur [4].

Tabel 1. Characteristic Responden

\begin{tabular}{|c|c|c|}
\hline Variable & Category & $\begin{array}{c}\text { Percentase } \\
(\%)\end{array}$ \\
\hline \multirow[t]{2}{*}{ Gender } & Male & $20 \%$ \\
\hline & Female & $80 \%$ \\
\hline \multirow[t]{4}{*}{ Age } & $18-24$ & $8 \%$ \\
\hline & $25-29$ & $43 \%$ \\
\hline & $36-40$ & $38 \%$ \\
\hline & $41-45$ Years & $13 \%$ \\
\hline \multirow[t]{6}{*}{ Profession } & Operational Staff & $13 \%$ \\
\hline & Manajeral Staff & $18 \%$ \\
\hline & $\begin{array}{l}\text { Professionals (Doctors, Notaries, } \\
\text { awyers, Artists, Etc.) }\end{array}$ & $20 \%$ \\
\hline & College Student & $8 \%$ \\
\hline & Hous ewife & $15 \%$ \\
\hline & Entrepreneur & $28 \%$ \\
\hline \multirow{5}{*}{$\begin{array}{l}\text { Expenditure } \\
\text { (Monthly) }\end{array}$} & IDR 800.000 -IDR $\quad 1.600 .000$ & $3 \%$ \\
\hline & IDR 1.000 .001 - IDR 2.200 .000 & $15 \%$ \\
\hline & IDR 2.200.001 - IDR 2.800.000 & $8 \%$ \\
\hline & IDR 2.800 .001 - IDR 3.400 .000 & $23 \%$ \\
\hline & Above Rp 3.400 .000 & $53 \%$ \\
\hline $\begin{array}{l}\text { Experience Shopping For Fumiture } \\
\text { And Accessories Online Media } \\
\text { Shopping }\end{array}$ & Yes & $100 \%$ \\
\hline \multirow[t]{2}{*}{ Platform Online } & Online Shoping Only & $33 \%$ \\
\hline & Conventional And Online Shopping & $68 \%$ \\
\hline
\end{tabular}

\section{Results and Discussion}

\subsection{Analysis Emphaty Map}

The discussion on the empathy map comes from two sequential methods. The first method uses interviews conducted to two groups of respondents, and the 
second method by distributing questionnaires to 40 respondents. The data obtained by the researcher were further described in six parts of the formulation of the empathy map, namely the parts that were seen, felt and thought, said and done, heard, pain, and desire. The formulation of the empathy map was then used by researchers as a guideline for designing the Cozzy.com business model.

The discussion on the empathy map comes from two sequential methods. The first method uses interviews conducted to two groups of respondents, and the second method by distributing questionnaires to 40 respondents. In-depth interviews were conducted with respondents from furniture and accessories traders, as well as potential customers. Meanwhile, the questionnaire was conducted on respondents from formal and institutional workforce backgrounds, entrepreneurs, housewives, and students. Both methods use a series of six questions from the empathy map. This technique is done by exploring the views or insights of several respondents, in this case as producers and consumers of furniture and accessory products.

Table 2. Emphaty Map Interview Result

\begin{tabular}{|c|c|c|}
\hline No. & Variabel & Result \\
\hline & What did he/she see? & $\begin{array}{l}\text { The products on the market today are less varied and less } \\
\text { trend- following. }\end{array}$ \\
\hline 2. & What did he/she hear? & $\begin{array}{l}\text { The recommendation factor from friends } \\
\text { and relatives influences respondents to purchase furniture } \\
\text { products. }\end{array}$ \\
\hline & $\begin{array}{l}\text { What was he/she really } \\
\text { thinking and feeling? }\end{array}$ & $\begin{array}{l}\text { Custom product limitations or in accordance with } \\
\text { the size of the room and the desired design. }\end{array}$ \\
\hline & What did it say and do? & $\begin{array}{l}\text { The product received is often not in accordance with the } \\
\text { image shown, causing disappointment, and will tell his } \\
\text { disappointment to family and friends. }\end{array}$ \\
\hline & $\begin{array}{l}\text { What paint do customers } \\
\text { feel? }\end{array}$ & $\begin{array}{l}\text { The trust factor in online shopping is still an } \\
\text { obstacle for customers. }\end{array}$ \\
\hline & What are the customergains? & $\begin{array}{l}\text { Products with attractive designs, varied, and can be ordered } \\
\text { to order. Also, product warranties, and promos and } \\
\text { discounts are aspects that customers want. }\end{array}$ \\
\hline
\end{tabular}

\subsection{What Customers See}

The second question of the empathy map is what the customer sees. This question describes the problems seen by research subjects related to problems in buying furniture and accessories products. Based on the results of the survey conducted, it was explained that as many as $68 \%$ of respondents bought furniture and accessories products through physical and online stores. Meanwhile, 45\% of respondents stated that shopping for furniture and accessories online can save them time. In addition, $58 \%$ of respondents considered shopping online an attractive thing. Apart from being able to save time, shopping online also gives customers a wide choice of products and brands as evidenced by the statements of $48 \%$ of respondents.

Based on the results of the interview, the sources stated that it was difficult to get a product with a unique design and according to taste. Besides that, the resource person also explained that the products on the market today are less varied and do not keep up with trends. This statement is explained through the following interview results. 
“... the existing products are quite a lot but, the variations are not up to date."(R1)

"I rarely buy products on buying and selling websites, because I haven't found them yet products according to taste." (R2)

The results of the survey and interviews explain several important things that were seen by respondents in obtaining furniture and accessories products. First, respondents made purchases of furniture and accessories through online media and physical stores. Second, design limitations are still an obstacle for respondents in finding products that match their wishes. The third factor is that respondents perceive that shopping online can save time and have a large selection of products and brands.

The results of researchers' observations on December 5, 2016 through 10 sites that sell furniture and accessories products specifically or in general. Researchers found four sites such as, Qlapa.com, Fabelio.com, Ikea.co.id, and Livaza which offer products with unique designs but do not provide a choice of product design variations. As stated by Leahy [10], industrialist, vintage, retro, and classic furniture designs are customer favorites in 2015-2017. This statement is supported by respondents' statements stating that industrialist $(53 \%)$, Vintage $(43 \%)$, and Retro $(33 \%)$ product designs are preferred product designs.

\subsection{What Customers Hear}

The second question is what customers hear about who and what information can influence customers to buy furniture and accessories products. The survey results obtained indicate that friends and family are the influencing factors in buying furniture and accessories products. As much as $78 \%$ of respondents stated that friends and family recommendations were the main factor in buying products. Respondents obtained information on furniture and accessories products through social media, such as Instagram, Facebook, Twitter, and Pinterest. As many as $85 \%$ of respondents obtained information through social media Instagram, and $40 \%$ through social media paths. In addition, $45 \%$ of respondents also obtain information on furniture and accessories products through electronic magazine portals. As many as $55 \%$ of respondents also stated that they would be motivated to make purchases after obtaining information from friends and family, as well as electronic media.

Based on the results of interviews with sources who are potential customers of Cozzy.com. Resource persons obtain information about furniture and accessories products through friends and close relatives, as well as online media.

“... friends tell me about a good place, then good designs, the same if there's a promo or discount ...”(R1)

"I have a friend whose hobby is hunting vintage items. So, we often share when there are products with a good custom place... He also often shows pictures, website links, and good decoration magazines. " (R2)

Based on the results of surveys and interviews, it shows that the factor of friend recommendations and information through social media influences respondents to purchase furniture and accessories. As many as $18 \%$ of respondents choose to find information on their own furniture and accessories thro ugh search engines such as Google and Yahoo. 


\subsection{What was he/she really thinking and feeling?}

The third question is what the customer feels and thinks. This section describes Cozzy.com's considerations in capturing customer value. Based on the results of interviews with two respondents, it was explained that today's customers find it difficult to find products that match the size of the room and the desired design. The following is a snippet of interviews with respondents.

“.. Now there are many cafes and places to eat with good concepts, then look at interior designs on the internet. Well, sometimes I really have... If you want to go hunting to malls or furniture stores, it's really complicated ... " (R1)

The results of the questionnaire to 40 prospective Cozzy.com customers from five answers about the main factors of respondents' interest in buying furniture and accessories products, as many as $28 \%$ of respondents answered that the design aspect was the main factor. Based on the seven existing furniture designs, they are industrialist, vintage, retro, pop art, Scandinavian, bohemian, and minimalist modern. As many as $60 \%$ of respondents found it difficult to find the product.

Based on the question of respondents' interest in customized services,as many as $85 \%$ of respondents stated that they were interested in customized products. The reason for this interest is that as many as $45 \%$ of respondents can adjust the shape, color and design as desired. Meanwhile, $37 \%$ of respondents stated that they could adjust the product to the size of the room. One of the informants stated that the reason for buying products to order was due to the difficulty in finding products with the desired design. The following is an excerpt from the interview with the interviewee:

" We really have trouble finding the product. The number is we are more than happy to find custom place. " (R2)

On the other hand, furniture traders feel that the electronic market currently offers products in general and no one has yet specialized in furniture products. Therefore, traders must compete with other products such as electronics, fashion, and other types of products. The following is the respondent's statement regarding this matter:

"... like in Tokopedia and Bukalapak even though our products are already at a premium Very rarely on the start page ... " (Pl)

Based on the results of interviews and questionnaires, it can be concluded that the respondent wants a product with a design that is in accordance with the characteristics and the product according to the order. Meanwhile, traders find it difficult to compete with other types of products in the current electronic market.

\subsection{What did it Say and Do?}

The fourth question is what the customer feels and thinks. This section describes what customers might say and do in buying furniture and accessories online. Based on the results of a survey conducted, $38 \%$ of respondents bought products with minimalist modern designs, $28 \%$ of Scandinavian designs, and $23 \%$ of respondents bought 
products with vintage designs. Meanwhile, respondents stated that accessory products are products that are often purchased online and $30 \%$ of respondents buy furniture products online. More deeply, the accessory product items that respondents usually buy are small pillows, wall hangings, and action figures. In furniture products, product items purchased by customers are small cabinets, chairs and tables. In detail, $58 \%$ of respondents bought furniture products online with a price range of IDR $500,000-$ IDR $1,500,000$, and $53 \%$ purchased a price range of IDR 1,500,001-IDR $2,500,000$.

When the respondent is not satisfied with the product received, for example, the product does not match the image and the product received is damaged. Based on the survey results, $65 \%$ of respondents will ask to exchange goods. As a follow-up to the disappointment received, $33 \%$ of the responses would not buy the same place and tell their family and friends about their disappointment. Two sources also stated the same thing, where the resource person would hold him responsible for a product that was not in accordance with what was received. The following is an excerpt from the interview with the resource person.

"... asking for compensation by returning the money or replacing it with new goods, and of course it is impossible to buy there again." (R1)

"... if it is damaged because of poor quality, it's not our negligence, of course they have to take responsibility." (R2)

On the furniture and accessory products merchant side, it is stated that the product displayed is given a detailed description so that customers know the ingredients and products being sold.

Respond to complaints experienced by customers such as product damage caused by shipping. Traders are willing to repair damaged goods caused by delivery, provided that the complaint is not more than 24 hours at the time the goods are received. Meanwhile, the cost of shipping is fully borne by the customer. As a form of company service, merchants provide a product warranty for 30 days in the event of damage that does not come from customer negligence. The following is an excerpt from the interview with the interviewee:

"... we repair the product at no additional cost, but on condition that the item arrives must be photographed and not more than 24 hours. The second condition is that they bear the shipping costs. "(P1)

"We explain the product in as much detail as possible ... there is a guarantee from us for 30 days, if the product is not suitable and keeps getting damaged even though it has only been repackaged for less than a month" (P2)

\subsection{What Pain do Customers Feel?}

The fifth question is the respondent's response to the complaints felt by customers. Based on the results of interviews with two sources, it is stated that the trust factor is the main indicator in online shopping. This fact is supported by the results of a survey to potential customers which stated that the product purchased was not in accordance with what was ordered by $48 \%$. Security is the second factor of concern for responses in shopping for furniture and accessories online, at $43 \%$. The following is the 
statement of the source regarding this matter.

"So the fear is if the goods do not arrive, are late, and the goods are damaged or notsuitable." (R1)

"..The goods don't match what is drawn, due to factors the lighting is the same as the camera. " (R2)

The factor of customer trust in the products offered is an obstacle in shopping online. This factor is related to the level of safety and conformity of the product in the image with the product received.

\subsection{What Customer Gain}

The sixth question is the achievement that the customer considers important. In this section, the author wants to know what customers want from the sales service for furniture and accessories products. The survey results show that as many as $85 \%$ of respondents want products to order. Respondents also stated that they wanted promo and discount programs, product warranties, and low shipping costs. In addition, the results of the interviews explained that engagement with wellknown furniture designers can increase customer trust. The following is an excerpt from interviews with potential Cozzy.com customers.

"Discounts are the most, but discounts are not just promotional discounts. Price just get discounted, that's the same. " (R1)

"... There is collaboration with designers if possible, famous designers. Let us be sure that the products offered are cool and have good quality. " (R2)

The results of surveys and interviews show that customers want products with attractive, varied designs and can be ordered to order. In addition, product warranties, promos and discounts are aspects that customers want. The survey and interview results obtained were then formulated into an empathy map, which can be seen more clearly in Table 3 .

Tabel 3. Emphaty Map Result

\begin{tabular}{cll}
\hline Variabel & \multicolumn{3}{c}{ Result } \\
\hline See? & 1. Merchant have difficulty finding their market \\
& 2. Customer are not satisfied with the products on the market \\
& 3. Product on the market do not follow the trend \\
& 4. Buy interior products through the media website \\
5. Selling products through online shops and social media & 1. Friends \\
& 2. Social Media (Facebook, Instagram) \\
Think \& Feel? & 3. E-Mail Difficult to find products with industrialist, vintage, retro, pop \\
& 2. There is no online shop specializing in interior products \\
Say \& Do? & 1. Product warranty for 30 days \\
& 2. Often buy accessory products online, especiall small \\
& 3. Requesting the exchange of inappropriate items \\
& 4. Buying a price range of IDR 100,000-IDR 500,000 & \\
\hline
\end{tabular}




\begin{tabular}{cl}
\hline Variabel & \\
\hline \multirow{3}{*}{ Paint? } & 5. Telling friends about disappointment \\
& 1. Trust and shopping safety \\
& 2. High shipping costs \\
Gain? & 3. Goods sent do not match the picture \\
& 2. Promo dan discounts \\
& 3. Product Warranty \\
& 4. Theap Shipping Cost \\
\hline
\end{tabular}

The information obtained from interviews and surveys is briefly shown in table 3. This information forms the basis for the creation of value for customers, which is then designed into the Cozzy.com business model canvas.

\subsection{Business Model Canvas}

In this study, the authors describe a business model using a business model canvas developed by Osterwalder \& Pigneur (2010). This concept describes the whole business on a single canvas that contains nine block elements. Cozzy.com's business model canvas can be seen in Table 4.

Table 4. Innovation Business Model Canvas Cozzy.com

\begin{tabular}{|c|c|}
\hline BMC Variabel & Cozy Indonesia \\
\hline Customer Segment & $\begin{array}{l}\text { 1. Customers who need a vanety of interior products } \\
\text { 2. Selling interior products that have style } \\
\text { specifications }\end{array}$ \\
\hline Value Proposition & $\begin{array}{l}\text { 1. Custom Product } \\
\text { 2. Various Products } \\
\text { 3. Product Warranty } 365 \text { day } \\
\text { 4. Capital Funding } \\
\text { 5. Data Base Management } \\
\text { 6. Access to find customer }\end{array}$ \\
\hline Channels & $\begin{array}{l}\text { 1. Website } \\
\text { 2. Instagram dan Facebook } \\
\text { 3. Youtube Channel }\end{array}$ \\
\hline Customer Relationship & 1. Customer Service 24 Jam \\
\hline & 2. Give Away \\
\hline Revenue Streem & $\begin{array}{l}\text { 1. Cooperation Fee for Product Making to Order } \\
\text { 2. Cooperation Fee for Interior Product Sales } \\
\text { 3. Promotion Package (Membership) }\end{array}$ \\
\hline Key Activities & $\begin{array}{l}\text { 1. Customer Service } \\
\text { 2. Distributing designs to the furniture workshop } \\
\text { 3. Promotion }\end{array}$ \\
\hline Key Resources & $\begin{array}{ll}\text { 1. HR } \\
\text { 2. Technology } \\
\end{array}$ \\
\hline Key Partnership & $\begin{array}{l}\text { 1. Banking } \\
\text { 2. Leasing } \\
\text { 3. Furniture workshop } \\
\text { 4. BPJS Ketenagakerjaan } \\
\end{array}$ \\
\hline Cost Structure & $\begin{array}{l}\text { 1. IT } \\
\text { 2. Marketing } \\
\text { 3. Operational } \\
\text { 4. Insurance } \\
\text { 5. Loan Interest } \\
\text { 6. Tax }\end{array}$ \\
\hline
\end{tabular}




\section{Conclusion}

Based on the research results, a clear and detailed picture of a Cozzy.com innovation business model is mapped into nine blocks of the canvas business model, including the value proposition offered by Cozzy.com, namely custom products, various products, warranty 365 days, capital funding, data base management, access to find customers. The next block discusses the consumer segment which is divided into two types, namely customers and sellers of interior products. The business model innovation offered is a multisided platform. Where, the company will serve two customers side by side. As a company channel in reaching consumers through the website.

\section{References}

[1] Kementrian PU PR (2014). Kebijakan dan Strategi Penyediaan Perumahan TA 2015-2019. Tersedia http://pu.go.id/uploads/Materi-Rakortek-Penyediaan-Perumahan-TA-2015/Direktorat\% 20Perencanaan\%20Penyediaan\%20Perumahan.pdf. Diakses pada 12 April 2016.

[2] Colliers International (2016). Jakarta Property Market Report Q2 2016. Tersedia http://www.colliers.com/-/media/files/marketresearch/ap ac/indonesia/q2-2016-researchandforecastreport-jakarta.pdf?la=en-GB. Diakses pada 15 Agustus 2016

[3] Satriagung, Erlangga, Properti Menggerakkan Ekonomi. Diakses pada 15 Oktober 2016. Tersedia http://kanalsatu.com/id/post/48203/propertimenggerakkan-ekonomi. 2016.

[4] Widya. Osterwalder, A. The business model ntology a proposition in a design science approach. Universite de Lausanne, 2004.

[5] Ostewalder, A. and Yves Pigneur. Business Model Generation. New Jersey: , 2010

[6] Saino, L. Maija dan Saarenketo, Sami, Value Creation of an Internationalizing Entrepreneural Firm. Journal of Small and Enterprise Development.Vol. 18. Iss.3 pp. 556-570, 2016.

[7] Chesbrough, H. dan Schwartz, K. Innovating Business Models With coDevelopment, 2007

[8] Cosseboom, Leighton (2015). 10 Startups That Could be The Next Big Thing in Indonesia. Tersedia https://www.techinasia.com/indonesia-10-startups-formid-stage-investors-lists-2015. Diakses pada 13 April 2016.

[9] Cooper, Donald R dan Schindler, Pamela S, Business Research Methods Th 12 ed. Singapore: McGraw-Hill Education, 2014

[10] Leahy, Liana (2016). Interior Design Styles: 8 Popular Types Explained. Tersedia http://blog.froy.com/interior-design-styles-8-popular-types-explained/. Diakses pada 13 November 2016 